\title{
Human placental lactogen (hPL) deficiency in a normal pregnancy
}

\author{
OTTAVIO GIAMPIETRO \\ M.D.
}

\author{
MARCO FERDEGHINI \\ M.D.
}

\section{PAOLO SCATENA}

\begin{abstract}
II Medical Clinic and Center of Nuclear Medicine (Radioimmunoassy Section) of the University of Pisa; C.N.R. Clinical Physiology Institute of Pisa, Italy
\end{abstract}

\section{Summary}

A case of human placental lactogen (hPL) deficiency together with normal oestriol levels associated with a normal pregnancy in a woman in her second pregnancy is reported. The woman gave birth to a healthy male infant. The placenta was normal. Extremely low hPL levels may be compatible with the delivery of a healthy infant.

KEY WORDS: human placental lactogen, hPL, oestriol, pregnancy.

\section{Introduction}

In recent years measurements of serum concentrations of human placental lactogen (hPL) together with circulating levels of oestriol have been widely employed for the serial and accurate endocrine monitoring of pregnancy in order to evaluate and to assess intrauterine fetal well-being (Spellacy et al., 1971; Letchworth and Chard, 1972; Lindberg and Nilsson, 1973; Spellacy, Buhi and Birk, 1975). It is generally accepted that pregnancies with very low hPL levels are associated with maternal vascular problems, fetal delay of growth, and also with increased perinatal morbidity and mortality (Spellacy et al., 1975; Lebech and Borggaard, 1974; Moshirpur et al., 1981). Recently pregnancies have been described where very low levels or practically complete deficiency of hPL are associated with a normal gestation and the birth of normal babies, mostly male (Bock, Gaede and Trolle, 1976; Bradford and Hargreaves, 1978; Gaede, Trolle and Pedersen, 1978; Nielsen, Pedersen and Kampmann, 1979; Moshirpur et al., 1981; Di Renzo, Anceschi and Volpe, 1982); at least one normal female baby has also been delivered (Borody and Carlton, 1981). We report here a further case of hPL deficiency associated with normal oestriol levels in an otherwise

Correspondence: Ottavio Giampietro, M.D., Istituto di Fisiologia Clinica del C.N.R., Via Savi, 8, 56100 Pisa, Italy. normal pregnancy concluded with the delivery of a healthy male baby.

\section{Case report}

A 31-year-old woman, in her second pregnancy, had had an uncomplicated delivery of a healthy 3,500 g male baby 8 years before. The uterine size and the periodic ultrasound measurements were compatible with gestional age. However, after the first hPL determination at the 34th week gestation, which revealed an extremely low level of the hormone $(0.9 \mu \mathrm{g} / \mathrm{ml})$, she was admitted to our hospital. The patient remained normotensive and all routine urine and blood analysis continued to be normal. In the following weeks almost daily hPL concentrations ranged between 0.8 and $1.4 \mu \mathrm{g} / \mathrm{ml}$ (in our laboratory normal limits for the last 2 months of pregnancy range between $5 \cdot 85 \pm 1.3$ and $7 \cdot 1 \pm 1.4 \mu \mathrm{g} / \mathrm{ml}$ ). Total oestriol measurements, assayed on the same sera, gave values between 151 and $236 \mathrm{ng} / \mathrm{ml}$ (normal range for the corresponding pregnancy period is 42-284 ng/ml). Biparietal diameters also suggested normal fetal growth. The fetal heart rate became abnormal in the 39th week, with alternating periods of bradycardia and tachycardia. A caesarian section was performed with the delivery of a healthy male $3,060 \mathrm{~g}$ infant, $51 \mathrm{~cm}$ tall, with a cranial circumferance of $34 \mathrm{~cm}$, with Apgar scores of 10 at 1 and $5 \mathrm{~min}$. The placenta weighed $605 \mathrm{~g}$ with a diameter of $19 \mathrm{~cm}$ and looked normal; the umbilical cord was $28 \mathrm{~cm}$ long. The infant and the mother were discharged from the hospital on the 7th post-partum day both in a satisfactory condition.

\section{Materials and methods}

Serum hPL levels were determined by Radioimmunoassay Liso-phase hPL Kit (Lepetit SpA, Diagnostic Products, Milano). This method allows a 
detection of minimum hPL concentration of $0 \cdot 1$ $\mu \mathrm{g} / \mathrm{ml}$, employing $0.1 \mathrm{ml}$ of unknown serum sample, with a between-assay coefficient of variation of about $3.5 \%$. After 30 weeks of gestation, values of at least 4 $\mu \mathrm{g} / \mathrm{ml}$ are accepted as normal. The total serum oestriol levels were measured by Clinical Assays Travenol GammaDab Radioimmunoassay kit (Cambridge, Massachussets), which has a calculated sensitivity of $10 \mathrm{ng} / \mathrm{ml}$ employing $10 \mu \mathrm{l}$ of unknown serum sample, with a between-assay coefficient of variation of about $8 \%$.

All serum hPL and oestriol determinations were performed on patient's blood samples withdrawn at 8.00 a.m. in the fasting state and after a night's rest in bed.

\section{Discussion}

As in previously reported cases, our patient had extremely low hPL values together with total oestriol levels within normal limits, but pregnancy was normal and ended with delivery of a healthy male baby. It has been suggested that hPL deficiency may be sex-limited, as in sulphatase deficiency (Bock $e t$ al., 1976). In our patient, as in that of Moshirpur et al. (1981), Borody and Carlton (1981) and Di Renzo et al. (1982), the pregnancy with hPL deficiency was the second.

Although the importance of the measurement of a substance such as hPL produced in high quantities by the syncytiotrophoblasts of the placenta (Moshirpur et al., 1981) is well established for the monitoring of placental function in problematic and in clinically normal pregnancies (Spellacy et al., 1971; Letchworth and Chard, 1972; Lindberg and Nilsson, 1973, Spellacy et al., 1975) our case further indicates that extremely low levels of hPL may be compatible with a normal pregnancy and the delivery of a normal baby. However, in the same period we monitored another pregnancy in a primigravida woman also with extremely low hPL levels and normal oestriol concentrations which ended with the premature spontaneous delivery of a female infant who died after four days for respiratory distress.

It has been postulated that such low hPL levels may be consequent to a failure of placental synthesis (Nielsen et al., 1979; Borody and Carlton, 1981), or to $\stackrel{\triangle}{\complement}$ a more rapid destruction rate (Borody and Carlton,.. 1981); finally the presence of another molecule with $\vec{F}$ hPL-like activity but with different immunological $\stackrel{0}{?}$ characteristics cannot be excluded (Nielsen et al., 1979). The real cause of this very unusual condition remains to be elucidated.

\section{References}

Bock, J.E GAEDE, P. \& TROLLE, D. (1976) The prognostic and diagnostic value of total oestriol in urine and in serum and of $\vec{\omega}$ human placental lactogen in serum in the last part of pregnancy. $\sigma$ American Journal of Obstetrics and Gynecology, 126, 834.

BORODY, I.B. \& CARLTON, M.A. (1981) Isolated defect in human placental lactogen synthesis in a normal pregnancy. British Journal of Obstetrics and Gynaecology, 88, 447.

BRADFORD, W.P. \& HARGREAVES, T. (1978) Human placental lactogen in late pregnancy. Lancet, i, 1213.

Di RENZO, G.C., ANCESCHI, M.M. \& VOLPE, A. (1982) Deficiency of human placental lactogen in an otherwise normal pregnancy. $\infty$ Journal of Obstetrics and Gynaecology, 2, 153.

Gaede, T., Trolle, D. \& Pedersen, H. (1978) Extremely low hPL 음 values in an otherwise uneventful pregnancy preceding delivery of $\rightarrow$ a normal baby. Acta Obstetrica et Gynecologica Scandinavica, 57, 203.

LEBECH, P.E. \& BorggaARD, B. (1974) Serum levels of human chorionic somatomammotropin (HCS) in normal and abnormal pregnancies. Acta Endocrinologica (Kbh), 185, (suppl.) 35.

LETCHWORTH, A.T. \& CHARD, T. (1972) Placental lactogen as screening test for fetal distress and neonatal asphyxia. Lancet 704.

LINDBERG, B.S. \& NiLSSON, B.A. (1973) Human placental lactogen (hPL) levels in abnormal pregnancies. Journal of Obstetrics and Gynaecology, British Commonwealth, 80, 1046.

Moshirpur, J., BernetT, A., MCCARRICK, J. \& Allerhand, J. O (1981) hPL deficiency with normal estriol levels in a normal pregnancy. Obstetrics and Gynecology, 57, 6 (suppl.) 6s.

Nielsen, P.V., Pedersen, H., Kampmann, E.M. (1979) Absence of $\vec{F}$ human placental lactogen in an otherwise uneventful pregnancy. American Journal of Obstetrics and Gynecology, 135, 322.

SPELLACY, W.N., BUHI, W.C. \& BIRK, S.A. (1975) The effectiveness of human placental lactogen measurements as an adjunct in decreasing perinatal deaths. American Journal of Obstetrics and Gynecology, 121, 835.

SPEllacy, W.N., BUHI, W.C., SChram, J.D., BiRK, S.A. \& Mc CREARY, S.A. (1971) Control of human chorionic somatomammotropin levels during pregnancy. Obstetrics and Gynecology, 37, 567.

(Accepted 11 October 1983) 